\title{
Fruit-feeding butterflies (Lepidoptera: Nymphalidae) of the Área de Proteção Especial Manancial Mutuca, Nova Lima and Species list for the Region of Belo Horizonte, Minas Gerais, Brazil
}

\author{
André Roberto Melo Silva ${ }^{1,3,4}$, Douglas Vitor Pontes ${ }^{I}$, Marco Paulo Guimarães ${ }^{1,3}$, \\ Marina Vicente de Oliveira ${ }^{1}$, Lucas Tito Faria de Assis ${ }^{1}$ \& Marcio Uehara-Prado ${ }^{2}$ \\ ${ }^{1}$ Centro Universitário UNA, Faculdade de Ciências Biológicas e da Saúde, Rua Guajajaras, 175, Centro, \\ CEP 30180-100, Belo Horizonte, MG, Brazil. \\ ${ }^{2}$ Instituto Neotropical: Pesquisa e Conservação Caixa Postal 19009, CEP 81531-980, Curitiba, \\ PR, Brazil. \\ ${ }^{3}$ Rede de Pesquisa e Conservação de Lepidópteros de Minas Gerais, Belo Horizonte, MG, Brazil. \\ ${ }^{4}$ Corresponding author: André Roberto Melo Silva, e-mail: andrerml.hotmail.com
}

SILVA, A.R.M., PONTES, D.V., GUIMARÃES, M.P., OLIVEIRA, M.V., ASSIS, L.T.F., UEHARAPRADO, M. Fruit-feeding butterflies (Lepidoptera: Nymphalidae) of the Área de Proteção Especial Manancial Mutuca, Nova Lima and Species list for the Region of Belo Horizonte, Minas Gerais, Brazil. Biota Neotropica. 15(3): e20140118. http://dx.doi.org/10.1590/1676-06032015011814

\begin{abstract}
A study of the assembly of fruit-feeding butterflies in the Área de Proteção Especial Manancial Mutuca, Nova Lima, MG was conducted with the goal of inventorying the species of the site. Forty-two traps were used to attract fruit-feeding butterflies, divided between Cerrado (rupestrian field) and riparian vegetation, monthly over one year. 2245 butterflies, which belonged to 63 species, were recorded. Of this total, fourty-eight species were collected in the Cerrado, twenty-one exclusively in this environment, forty-two in riparian forest, fifteen being exclusive to this environment, and twenty-seven species were sampled in both environments. From the total of sampled species, thirty-five were considered rare, eight accessory species, and twenty constant species. Prepona deiphile deiphile (Charaxine) is classified as vulnerable on the Minas Gerais' list and on the national list of threatened species. The collector curve showed no clear trend to stabilization, suggesting that there are species still not sampled in the study area. Adding the data from field sampling to the information on species occurrence in the literature and in entomological collections, the current number of frugivorous butterflies species for the region of Belo Horizonte is 104. This result foregrounds the importance of APE Mutuca for maintaning a rich fauna of frugivorous butterflies to the area.
\end{abstract}

Keywords: Biodiversity, community, conservation, inventory, species richness.

SILVA, A.R.M., PONTES, D.V., GUIMARÃES, M.P., OLIVEIRA, M.V., ASSIS, L.T.F., UEHARAPRADO, M. Borboletas frugívoras (Lepidoptera: Nymphalidae) da Área de Proteção Especial Manancial Mutuca, Nova Lima e lista de espécies da região de Belo Horizonte, Minas Gerais, Brasil. Biota Neotropica. 15(3): e20140118. http://dx.doi.org/10.1590/1676-06032015011814

Resumo: Foi realizado um estudo da assembléia de borboletas frugívoras da Área de Proteção Especial Manancial Mutuca, Nova Lima-MG, com o objetivo de inventariar as espécies do local. Foram utilizadas 42 armadilhas atrativas para borboletas frugívoras, divididas entre mata ciliar e Cerrado (campo rupestre), mensalmente ao longo de um ano. Foram amostradas 2245 borboletas, pertencentes a 63 espécies. Deste total, 48 espécies foram coletadas no Cerrado, sendo 21 exclusivamente neste ambiente, 42 na Mata Ciliar com 15 exclusivas e 27 espécies foram amostradas nos dois ambientes. Do total de espécies amostradas, 35 foram consideradas raras, oito acessórias e 20 constantes. Prepona deiphile deiphile (Charaxine) encontra-se classificada como vulnerável na lista de Minas Gerais e na lista nacional de espécies ameaçadas. A curva do coletor não mostrou tendência nítida à estabilização, o que sugere que ainda existam espécies não amostradas na área de estudo. Somando-se aos dados de amostragem em campo, informações sobre ocorrência de espécies na literatura e em coleções entomológicas, o número atual de espécies de borboletas frugívoras para a região de Belo Horizonte é de 104. Esse resultado ressalta a importância da APE Mutuca na manutenção de uma fauna rica de borboletas frugívoras para a região.

Palavras-chave: Biodiversidade, comunidade, conservação, inventário, riqueza de espécies. 


\section{Introduction}

Biological diversity is being lost at a rapid pace (Wilson 1997) and habitat loss and degradation, especially deforestation, are among the factors that most contribute to species extinction events (Brown \& Lomolino 2006, Machado et al. 2005). The Cerrado is no exception to this global trend. Most of the biome has already been cleared out or transformed, by human action, into pastures, annual crops and other types of land use (Klink \& Machado 2005). Only in the State of Minas Gerais, approximately $75 \%$ of the original area of the Cerrado has been destroyed (Lins \& Mendonça 2000).

The transformations which have happened in this biome have brought great environmental damages, such as fragmentation and reduction of habitats, species extinction, invasion of exotic species, soil erosion, pollution of aquifers, changes in fire regime, imbalances in the carbon cycle and possibly changes in regional climate (Klink \& Machado 2005). The Cerrado is considered a global hotspot for being an area with high rate of endemism and less than $30 \%$ of remnant vegetation (Myers et al. 2000), and the conservation of its biodiversity should be considered a priority in Brazil. Inventories are important for filling gaps in our knowledge of local biodiversity, assisting in the identification of endemism and generating subsidies for conservation (Lewinsohn et al., 2005, Mielke et al., 2010, Ritter et al. 2011).

The Lepidoptera comprise approximately 160,000 species, 20,000 of which are butterflies, and in Brazil there should occur around 26,000 species, including over 3,000 butterflies (Brown 1996, Freitas \& Almeida 2012). Among the butterflies, the Nymphalidae family is responsible for a significant portion of the species richness in the Neotropical region (DeVries et al. 1997), representing approximately $30 \%$ of this fauna (Lamas 2004). 'Charismatic' insects, such as butterflies, have the potential to become flagship groups in conservation programs (Lewinsohn et al. 2005). Butterflies are also considered good biological indicators as they respond quickly to environmental changes and are easily observed and sampled (Freitas et al., 2003, Freitas 2010).

Butterflies can be separated into two guilds, considering the eating habits of adults: nectarivorous, which feed on nectar; and frugivorous, which feed on fermented fruit, excrements, plants' exudates and decaying animals (Uehara-Prado et al. 2004). All the strict frugivorous belong to the Nymphalidae family, and represent $20 \%$ of neotropical butterflies (Lamas 2004). The frugivorous butterflies are divided into four subfamilies and 13 tribes: Satyrinae (Brassolini, Haeterini, Melanitini, Morphini e Satyrini), Charaxinae (Anaeini e Preponini), Biblidinae (Ageroniini, Biblidini, Callicorini, Epicalini e Epiphilini) e Nymphalinae (Coeini) (Marín et al. 2011). For the sampling of those butterflies, traps containing fermented fruit as bait have been vastly used in the tropics (De Vries et al. 1999, Uehara-Prado et al., 2004, Marini-Filho \& Martins, 2010, De Vries et al. 2011, Silva et al. 2012).

Only a few studies have been conducted with fruit-feeding butterflies in Cerrado areas, such as Pinheiro \& Ortiz (1992) in Brasilia, Fortunato \& Ruszczyk (1997) in Uberlândia, MariniFilho \& Martins (2010) in the Parque Nacional da Serra da Canastra and Silva et al. (2012) in Belo Horizonte. In this context, knowing the assemblage of fruit-feeding butterflies in Cerrado areas can generate data for further evaluation of the local biodiversity conservation. In this paper, a inventory of fruit-feeding butterflies from the Área de Proteção Especial (APE) Manancial Mutuca is presented. Moreover, the resulting list was supplemented with data from the occurrence of fruitfeeding butterflies in the region of Belo Horizonte.

\section{Material e Methods}

\section{The study area}

The study was conducted at a Área de Proteção Especial (Special Protection Area) Manancial Mutuca (2000'3723" S and $43^{\circ} 58^{\prime} 8,92^{\prime}$ ' W), a propriety of the Sanitation Company of Minas Gerais (COPASA - MG). The reserve is located in Nova Lima, Minas Gerais State, in the Ferriferous four-side. It is nestled in the Parque Estadual da Serra do Rola Moça, having joint administration with the State Forest Institute (SFI) and it borders the BR-040, two large mining companies and part of the Barreiro district in Belo Horizonte.

The APE Mutuca is 1250 hectares, with transitional vegetation between Cerrado and Atlantic Forest, with 371 hectares of arboreal coverage, including riparian zone of the Mutuca stream (Copasa 2013) (Figure 1). In this stream, there is a dam to capture water, composing, along with Cercadinho and Fechos reserves, the Supply System Morro Redondo, which provides water for a part of Nova Lima and southern area of Belo Horizonte (Copasa 2013).

In this region the climate is high-altitude tropical, characterized by dry winters and rainy summers (Brandão et al. 1997). The annual average temperature varies between $18^{\circ}$ and $21^{\circ} \mathrm{C}$. The rainfall shows variation between 1300-2100 mm annual rainfall, with the dry season between April and July and the rainy season starting in August (Cetec 1993).

The samplings were held in both of Cerrado phytophysiognomies present in the area: riparian vegetation and rupestrian field. The rupestrian field is found in areas above a thousand feet high, along the Serra do Espinhaço, in rocky or sandy soils and its vegetation consists of herbs and sparse shrubs (Mendonça \& Lins 2000). The riparian forest is a formation located along minor rivers and streams, but it is now reduced to scattered clumps (Mendonça \& Lins 2000).

\section{Sampling}

Samples were collected monthly for one year (from October 2008 to September 2009) during four days per month, the first day being for the installation of traps and placement of bait (banana with sugar cane juice, prepared two days in advance). Van Someren-Rydon traps, consisting of a cylinder of tulle of approximately eighty centimetres high, closed at the top and mounted on a wooden platform where the bait lies (DeVries 1987) were used.

Twenty-one traps were placed in the riparian area and other twenty-one in the Cerrado (rupestrian field), organized into sampling units (UA) with three traps. Within an UA, the traps were set twenty meters apart from each other and each UA was 200 meters away from the other.

When possible, captured specimens were identified in the field, marked and released. The unidentified specimens were collected for later identification. At least two individuals of each species were collected and assembled, and this reference collection is deposited in the Laboratory of Zoology of the 


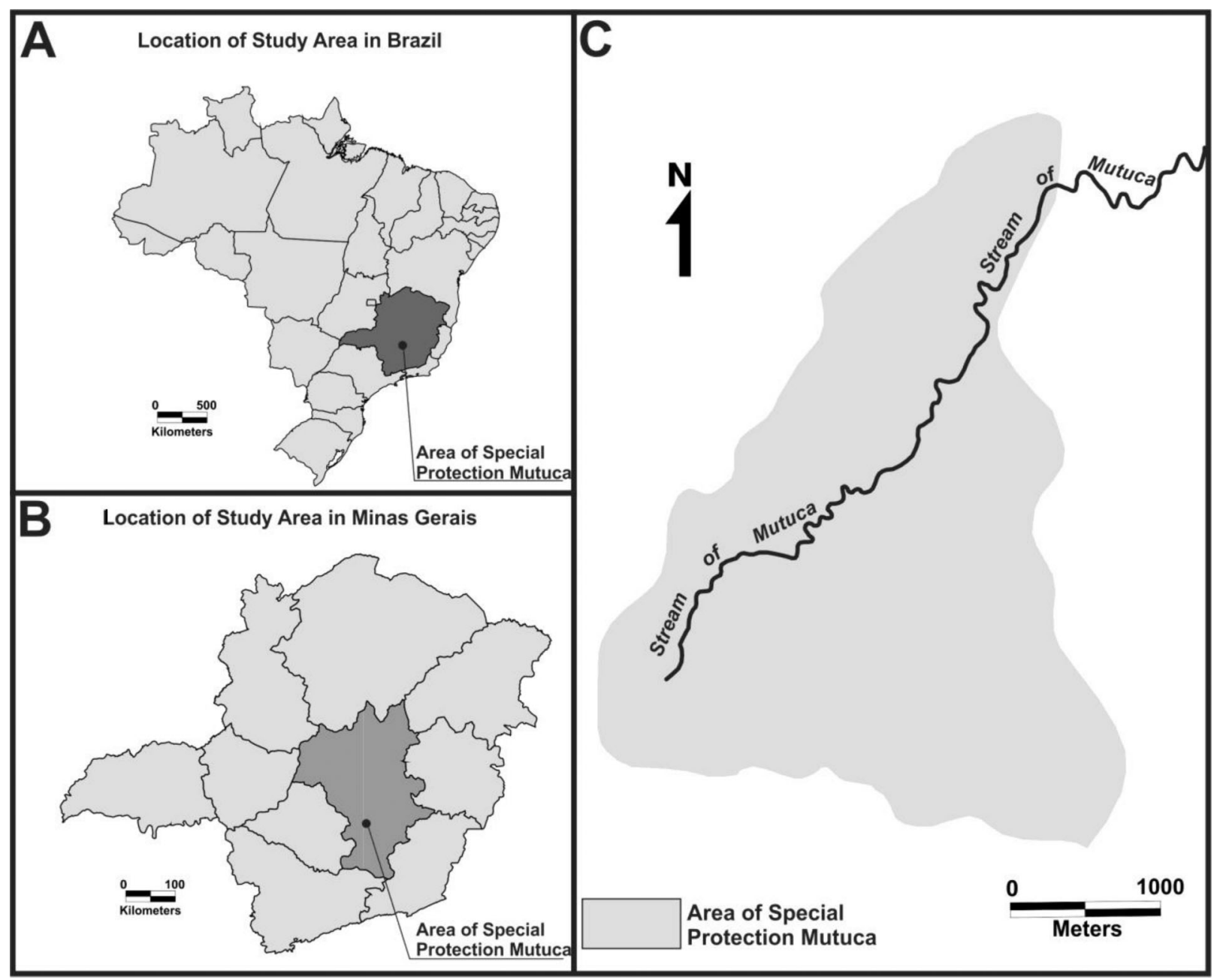

Figure 1. Location of Área de Proteção Especial Manancial Mutuca. A. Location of study area in Brazil, B. Location of study area in Minas Gerais and C. APE Mutuca.

Centro Universitário UNA at Belo Horizonte. The nomenclature used was based on Lamas (2004).

To complement the local species list, three collections containing butterflies from neighbouring cities to Belo Horizonte and Nova Lima and that had similar ecosystems were consulted: Collection of the Museu de História Natural e Jardim Botânico da UFMG (MHNJB-UFMG), the Entomological Collection of the Museu de Ciências Naturais Puc Minas (MCN-PUC-MG) and the Coleção Entomológica das Coleções Taxonômicas da UFMG. Additionally, data from four studies on butterflies of the city of Belo Horizonte were included (Brown \& Mielke 1968, Silva et al. 2007, Silva et al. 2012, Soares et al. 2012).

\section{Analysis of data}

The species accumulation curve (Mau Tau) and three richness estimators (Jackknife 2, Chao 2 and ACE) were calculated using the program EstimateS 8.2 (Cowel 2009). The percentage of the fauna in the field and the list supplemented with information from entomological collections and papers were compared to the estimates obtained. According to Magurran (2011), the nonparametric estimators are the most effective methods to estimate species richness in ecological assemblages.
Species present in over $50 \%$ of the sampled months were considered constant, species present between 25 and $50 \%$ (present between three and five months) were considered accessory and species present in less than $25 \%$ of samples (one or two samples) were considered rare (Dajoz 1983).

\section{Results and Discussion}

In all, 2245 specimens belonging to sixty-three species of fruit-feeding butterflies were sampled (Table 1). From the recorded species, one appears on the list of threatened Fauna of Minas Gerais (2006) and on the national list of threatened species (O.J. Marini-Filho, unpublished data): Prepona deiphile deiphile (Charaxinae), classified as vulnerable on both lists (Figure 2).

The Satyrinae subfamily was the most abundant with 1637 specimens (73\%), followed by the Charaxinae with $348(15.5 \%)$, Biblidinae with $220(9.8 \%)$ and Nymphalinae with forty specimens $(1.7 \%)$. Regarding the overall richness, Satyrinae had thirty-one species, representing $49.2 \%$ of the sample (from Satyrini, there were nineteen species, $80.9 \%$, from Brassolini, nine species, $14.3 \%$, and from Morphini three, $4.8 \%$ ), followed by Biblidinae with seventeen species $(27 \%)$, Charaxinae with twelve species (19\%) and Nymphalinae with three species $(4.8 \%)$, 
Table 1. Species list, constancy and abundance of fruit-feeding butterflies species (Nymphalidae), in the rupestrian fields and riparian forest from the Área de Proteção Especial Manancial Mutuca, Nova Lima, MG, Brazil, (October 2008 and September 2009) and species found in the region of Belo Horizonte recorded in other studies.

\begin{tabular}{|c|c|c|c|c|}
\hline \multirow[b]{2}{*}{ Subfamilies/Species } & \multicolumn{3}{|c|}{ APE Mutuca } & \multirow[b]{2}{*}{$\begin{array}{c}\text { Recorded in collections and } \\
\text { literature }\end{array}$} \\
\hline & $\begin{array}{l}\text { rupestrian } \\
\text { field }\end{array}$ & $\begin{array}{l}\text { riparian } \\
\text { forest }\end{array}$ & constancy & \\
\hline \multicolumn{5}{|l|}{ Biblidinae } \\
\hline Biblis hyperia nectanabis (Fruhstorfer, 1909) & 1 & - & $\mathrm{R}$ & $\mathrm{a}, \mathrm{b}, \mathrm{d}, \mathrm{e}, \mathrm{f}$ \\
\hline Callicore astarte selima (Guenée1872) & & & & $\mathrm{a}, \mathrm{b}, \mathrm{d}, \mathrm{e}$ \\
\hline Callicore pygas thamyras (Ménétriés, 1857) & 1 & - & $\mathrm{R}$ & $\mathrm{b}, \mathrm{e}, \mathrm{f}, \mathrm{g}$ \\
\hline Callicore sorana sorana (Godart[1824]) & 128 & - & $\mathrm{C}$ & $a, b, c, d, e, f$ \\
\hline Catonephele numilia penthia (Hewitson, 1852) & - & 2 & $\mathrm{R}$ & $\mathrm{e}$ \\
\hline Catonephele sabrina (Hewitson, 1852) & & & & $\mathrm{b}$ \\
\hline Cybdelis phaesyla (Hübner, [1831]) & & & & $\mathrm{b}, \mathrm{d}$ \\
\hline Diaethria candrena (Godart[1824]) & 1 & - & $\mathrm{R}$ & $\mathrm{b}, \mathrm{d}, \mathrm{e}, \mathrm{f}$ \\
\hline Diaethria clymena (Cramer, 1775) & 1 & - & $\mathrm{R}$ & $\mathrm{b}, \mathrm{d}, \mathrm{f}$ \\
\hline Diaethria eluina eluina (Hewitson, 1855) & & & & $\mathrm{b}$ \\
\hline Ectima thecla (Fabricius, 1796) & - & 1 & $\mathrm{R}$ & $\mathrm{g}$ \\
\hline Epiphile hubneri Hewitson, 1861 & 6 & 32 & $\mathrm{C}$ & $\mathrm{b}, \mathrm{d}, \mathrm{f}$ \\
\hline Epiphile orea (Hubner[1823]) & - & 13 & A & $\mathrm{b}, \mathrm{d}$ \\
\hline Eunica bechina magnipunctata Talbot, 1928 & & & & $\mathrm{~b}, \mathrm{f}$ \\
\hline Eunica cuvierii (Godart, 1819) & & & & $\mathrm{f}$ \\
\hline Eunica eburnea Fruhstorfer, 1907 & & & & $\mathrm{~d}$ \\
\hline Eunica margarita (Godart, [1824]) & & & & $\mathrm{b}, \mathrm{e}$ \\
\hline Eunica tatila bellaria Fruhstorfer, 1908 & 9 & - & $\mathrm{R}$ & $\mathrm{d}$ \\
\hline $\begin{array}{l}\text { Hamadryas amphinome amphinome } \\
\text { (Linnaeus, 1767) }\end{array}$ & 1 & - & $\mathrm{R}$ & $a, b, d, e, f, g$ \\
\hline Hamadryas chloe rhea (Fruhstorfer, 1907) & - & 1 & $\mathrm{R}$ & $\mathrm{d}, \mathrm{e}$ \\
\hline Hamadryas epinome (C. Felder \& R. Felder, 1867) & & & & $\mathrm{b}, \mathrm{c}, \mathrm{d}, \mathrm{e}, \mathrm{f}, \mathrm{g}$ \\
\hline Hamadryas februa februa (Hübner, 1823) & 13 & - & $\mathrm{C}$ & $\mathrm{a}, \mathrm{b}, \mathrm{c}, \mathrm{d}, \mathrm{e}, \mathrm{f}, \mathrm{g}$ \\
\hline Hamadryas feronia feronia (Linnaeus, 1758) & 1 & 1 & $\mathrm{R}$ & $\mathrm{a}, \mathrm{b}, \mathrm{c}, \mathrm{e}, \mathrm{f}, \mathrm{g}$ \\
\hline Hamadryas fornax fornax (Hübner, [1823]) & & & & $\mathrm{e}$ \\
\hline Hamadryas iphthime iphthime (H. W. Bates, 1864) & - & 1 & $\mathrm{R}$ & $\mathrm{g}$ \\
\hline Hamadryas laodamia laodamia (Cramer, 1777) & & & & $\mathrm{a}, \mathrm{b}, \mathrm{e}, \mathrm{g}$ \\
\hline Myscelia orsis (Drury, 1782) & - & 2 & $\mathrm{R}$ & \\
\hline Nica flavilla (Godart, [1824]) & & & & $\mathrm{a}$ \\
\hline Temenis laothoe meridionalis Ebert, 1965 & 5 & - & $\mathrm{R}$ & $\mathrm{b}, \mathrm{c}, \mathrm{d}, \mathrm{f}$ \\
\hline \multicolumn{5}{|l|}{ Nymphalinae } \\
\hline Colobura dirce (Linnaeus, 1758) & 1 & 23 & $\mathrm{C}$ & $a, b, d, e, f, g$ \\
\hline Historis odius (Fabricius, 1775) & 10 & - & A & $\mathrm{c}, \mathrm{f}$ \\
\hline Smyrna blomfildia (Fabricius, 1781) & 4 & 2 & A & $e, f$ \\
\hline \multicolumn{5}{|l|}{ Charaxinae } \\
\hline Archaeoprepona amphimachus (Fabricius, 1775) & 37 & 14 & $\mathrm{C}$ & $\mathrm{d}, \mathrm{e}$ \\
\hline Archaeoprepona chalciope (Hubner, [1823]) & 2 & 9 & $\mathrm{R}$ & $\mathrm{d}, \mathrm{e}, \mathrm{f}$ \\
\hline Archaeoprepona demophon thalpius (Hubner, [1814]) & 7 & 6 & $\mathrm{C}$ & $a, b, d, f$ \\
\hline Archaeoprepona demophoon (Hubner, [1814]) & 8 & 1 & A & d \\
\hline Fountainea ryphea (Cramer, 1775) & 22 & 16 & $\mathrm{C}$ & $\mathrm{b}, \mathrm{d}, \mathrm{e}, \mathrm{f}$ \\
\hline Hypna clytemnestra (Cramer, 1777) & & & & $\mathrm{b}, \mathrm{d}$ \\
\hline Memphis acidalia victoria (H. Druce, 1877) & & & & $\mathrm{b}$ \\
\hline Memphis appias (Hubner, [1825]) & 75 & 44 & $\mathrm{C}$ & $\mathrm{b}, \mathrm{d}, \mathrm{e}$ \\
\hline Memphis moruus stheno (Prittwitz, 1865) & 12 & 21 & $\mathrm{C}$ & $\mathrm{a}, \mathrm{d}, \mathrm{e}, \mathrm{f}$ \\
\hline Memphis otrere (Hubner, [1825]) & 22 & 28 & $\mathrm{C}$ & $\mathrm{b}, \mathrm{d}, \mathrm{e}$ \\
\hline Prepona deiphile deiphile (Godart, [1824]) & 2 & - & $\mathrm{R}$ & \\
\hline Prepona laertes (Hubner, [1811]) & 1 & - & $\mathrm{R}$ & \\
\hline Prepona pylene Hewitson, [1854] & 1 & - & $\mathrm{R}$ & $\mathrm{d}$ \\
\hline Siderone galanthis (Cramer, 1775) & & & & $\mathrm{d}, \mathrm{e}, \mathrm{f}$ \\
\hline Zaretis isidora (Cramer, 1779) & 15 & 5 & $\mathrm{C}$ & $\mathrm{b}, \mathrm{d}, \mathrm{e}, \mathrm{f}$ \\
\hline
\end{tabular}


APE Mutuca

Subfamilies/Species

rupestrian riparian field forest

12

Blepolenis batea batea (Hübner, 1821)

Brassolis sophorae laurentii Stichel, 1925

Caligo arisbe Hubner, [1822]

Caligo illioneus illioneus (Cramer, 1775)

Catoblepia amphirhoe (Hubner, [1825])

Catoblepia berecynthia (Cramer, 1777)

Dasyophthalma rusina (Godart, [1824])

Eryphanis reevesii (Doubleday, [1849])

Narope cyllarus Westwood, 1851

Narope cyllastros Doubleday, [1849]

Opoptera syme (Hubner, [1821])

Opsiphanes cassiae (Linnaeus, 1758)

Opsiphanes invirae (Hubner, [1808])

Opsiphanes quiteria (Stoll, 1780)

Satyrinae: Morphini

Antirrhea archaea Hubner [1822]

Morpho anaxibia (Esper, [1801])

Morpho helenor mielkei (Blandin, 2007)

Morpho menelaus coeruleus (Perry, 1810)

Satyrinae: Satyrini

Capronnieria galesus (Godart, [1824])

Cissia terrestris (Butler, 1867)

Eteona tisiphone (Boisduval, 1836)

Euptychoides castrensis (Schaus, 1902)

Forsterinaria quantius (Godart, [1824])

Forsterinaria necys (Godart, [1824])

Forsterinaria pronophila (Butler, 1867)

Godartiana muscosa (Butler, 1870)

Hermeuptychia sp.

Carminda griseldis (Weymer, 1911)

Moneuptychia itapeva Freitas, 2007

Carminda paeon (Godart, [1824])

Moneuptychia soter (Butler, 1877)

Pareuptychia ocirrhoe interjecta (d'Almeida, 1952)

Pareuptychia ocirrhoe ocirrhoe (Fabricius, 1776)

Pareuptychia summandosa (Gosse, 1880)

Paryphthimoides phronius (Godart, [1824])

Paryphthimoides poltys (Prittwitz, 1865)

Paryphthimoides sp.

Paryphthimoides vetigiata (Butler, 1867)

Pharneuptychia innocentia (C. Felder \&

R. Felder, 1867)

Pierella nereis (Drury, 1782)

Taygetis acuta Weymer, 1910

Taygetis drogoni Siewert, Zacca, Dias \&

Freitas, 2013

Taygetis laches (Fabricius, 1793)

Taygetis rufomarginata Staudinger, 1888

Taygetis thamyra (Cramer, 1779)

Taygetis virgilia (Cramer, 1776)

Taygetomorpha celia (Cramer, 1779)

Yphthimoides affinis (Butler, 1867)
8

1

$-$

20

$-$

3

12

-

43

-

84

129

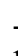

1

189

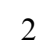

5

2

8
A

$\mathrm{R}$

$\mathrm{R}$

C

$\mathrm{R}$

$\mathrm{R}$

C

$\mathrm{R}$

$\mathrm{R}$

157

5

C

R a, b, c, d, e, f d, e

$\mathrm{d}, \mathrm{e}, \mathrm{f}$

$\mathrm{a}, \mathrm{b}, \mathrm{c}, \mathrm{e}$

$\mathrm{a}, \mathrm{b}, \mathrm{c}, \mathrm{d}, \mathrm{e}, \mathrm{f}$

b, d, e

\section{d}

d

b

$\mathrm{g}$

d, e, f

b, d, e

d, e

d

b, d, e, f

$a, b, d, e$

$\mathrm{e}$

d, e, f

d, e

d

$\mathrm{R}$

b, d, e

d

c, d, e, f, g

a, d, e, f, g

b

b, d, e, f

b, d

d, e

d, e, f

a, c, d, e, f

d

b

b, d, e

$\mathrm{f}$

$\mathrm{d}, \mathrm{g}$

Continued on next page 
APE Mutuca

\begin{tabular}{|c|c|c|c|c|}
\hline \multirow[b]{2}{*}{ Subfamilies/Species } & & \multirow[b]{2}{*}{$\begin{array}{c}\text { Recorded in collections and } \\
\text { literature }\end{array}$} \\
\hline & $\begin{array}{l}\text { rupestrian } \\
\text { field }\end{array}$ & $\begin{array}{l}\text { riparian } \\
\text { forest }\end{array}$ & constancy & \\
\hline Yphthimoides angularis (Butler, 1867) & & & & $\mathrm{b}, \mathrm{d}, \mathrm{e}$ \\
\hline Yphthimoides celmis (Godart, [1824]) & 8 & - & $\mathrm{R}$ & $\mathrm{b}, \mathrm{d}, \mathrm{e}, \mathrm{f}$ \\
\hline Yphthimoides saltuensis & 126 & 1 & A & $\mathrm{d}, \mathrm{e}, \mathrm{f}$ \\
\hline Yphthimoides ochracea (Butler, 1867) & 11 & 5 & A & $\mathrm{d}, \mathrm{e}, \mathrm{f}$ \\
\hline Yphthimoides pacta (Weymer, 1911) & 1 & - & $\mathrm{R}$ & $\mathrm{d}, \mathrm{e}$ \\
\hline Yphthimoides renata (Stoll, 1780) & & & & $\mathrm{d}, \mathrm{e}, \mathrm{f}, \mathrm{g}$ \\
\hline Yphthimoides straminea (Butler, 1867) & & & & $\mathrm{e}^{-30}$ \\
\hline $\begin{array}{l}\text { Yphthimoides yphthima (C. Felder \& } \\
\text { R. Felder, 1867) }\end{array}$ & & & & $\mathrm{d}, \mathrm{e}$ \\
\hline Zischkaia pacarus (Godart, [1824]) & & & & $\mathrm{d}$ \\
\hline Total & 1063 & 1182 & & \\
\hline
\end{tabular}

$\mathrm{C}=$ Constant, $\mathrm{A}=$ Accessory and $\mathrm{R}=$ Rare; $\mathrm{a}=$ Silva et al. (2007); $\mathrm{b}=$ Brown \& Mielke (1968); $\mathrm{c}=$ Collection of the MHNJB-UFMG; $\mathrm{d}=$ Entomological Collection of the MCN-PUC-MG; e = Entomological Collection of the Taxonomic Collections of UFMG; $\mathrm{f}=$ Silva et al. (2012); $\mathrm{g}=$ Soares et al. (2012).

the same sequence mentioned by Lamas (2004) regarding the richness of the butterflies subfamily of Nymphalidae in the Neotropical region.

A study conducted in APE Cercadinho, near APE Mutuca (Silva et al., 2012), found 78\% species of Satyrinae in sampling, and in both locations the richness of this subfamily was close to $50 \%$ of species in the sample. Indeed, Satyrinae usually occupies a prominent position in number of species in the studies of fruit-feeding butterflies (De Vries et al. 1997, De Vries et al. 1999). Studies in other areas of Cerrado in Minas Gerais also found Satyrinae as the group with the highest number of species (Marini-Filho \& Martins, 2010, Silva et al. 2012). This pattern is due to the fact that Satyrinae is the richest subfamily of fruit-feeding butterflies in the Neotropical region with 1235 species, having many more species than the second subfamily, Biblidinae, with 266 species (Lamas 2004).

From the total of sampled species, thirty-five were found to be rare $(56 \%)$, eight were considered accessory and twenty were considered constant (Table 1). From the thirty-five rare species, fourteen $(22 \%)$ were singletons and seven $(11 \%)$ doubletons. In insect assemblies, species represented by a single individual are prevalent (Magurran 2011). Pinheiro \& Ortiz (1992), in a study in Jardim Botânico de Brasília, found $26 \%$ of singletons and, in an area near APE Mutuca (APE Cercadinho) there were records of $18 \%$ of singletons (Silva et al., 2012), similar numbers to the ones in this paper.

According to Magurran (2011), in all environments (either tropical or temperate), most species in an assembly are rare, and a small number of common species will represent $90 \%$ of total abundance. As a matter of fact, in this study, ten species accounted for $71 \%$ of total abundance. The four most abundant species in the sample belong to the subfamily Satyrinae: Godartiana muscosa, with 550 specimens; Morpho helenor mielkei (200); Pharneuptychia innocentia (189) and Moneuptychia itapeva, with 130 specimens. Of these, three are small, being better able to survive in small fragments of habitat because their larvae require a smaller volume of host plants, having large populations (Shahabuddin \& Ponte 2005, Marini-Filho \& Martins 2010), what could explain the large abundances found. M. helenor was one of the most abundant species in riparian forests in the
Cerrado in the Parque Nacional da Serra do Canastra MG (Marini-Filho \& Martins 2010), showing similar results to the ones in the present study. Species of the genus Morpho can fly in the understory or canopy, and $M$. helenor flies to about one meter above ground along streams and forest edges (De Vries et al. 2010), being considered typical of riparian forest (Pinheiro et al. 2008), which may explain the great abundance of this butterfly in APE Mutuca, having 79\% of individuals sampled in this environment.

When considering the sampled environments, it was recorded in the rupestrian field 1063 specimens $(47.4 \%)$ of forty-eight species, twenty-one of which are exclusive to this environment, while in riparian area it was recorded 1182 specimens $(52.6 \%)$ belonging to forty-two species, fifteen of which were exclusive to this site (Table 1). According to Baz \& Boyero (1995), the structural heterogeneity of a place with distinct vegetation types is a favourable factor to increase diversity of butterflies. The various vegetation types recognized in the Cerrado region provide a spatial variation in the distribution of butterfly species, influencing the composition of their communities (Camargo 2001), supported by the large number of species exclusive to each environment in the present study. The establishment and persistence of butterfly populations in riparian forest and rupestrian field are related to the availability of resources for larvae and adults, vegetation type, climate and degree of disturbance, which certainly varies between these two sites in APE Mutuca, in addition to the intrinsic characteristics of the organisms involved, such as population dynamics, mobility and adaptability to disturbed environments (Fortunato \& Ruszczyk 1997).

Even when taking into account differences in relation to sampling effort, it is important to observe that the species richness of fruit-feeding butterflies APE Mutuca was similar or greater when compared to other sites in Cerrado. The APE Mutuca showed greater richness other places, such as APE Cercadinho in Belo Horizonte, a very similar and nearby area, where forty-five species (Silva et al. 2012) were recorded; in Uberlandia, where thirty-six species were found in urban and extra urban areas (Fortunato \& Ruszczyk 1997); in Jardim Botânico de Brasília, where forty-six species were recorded in 


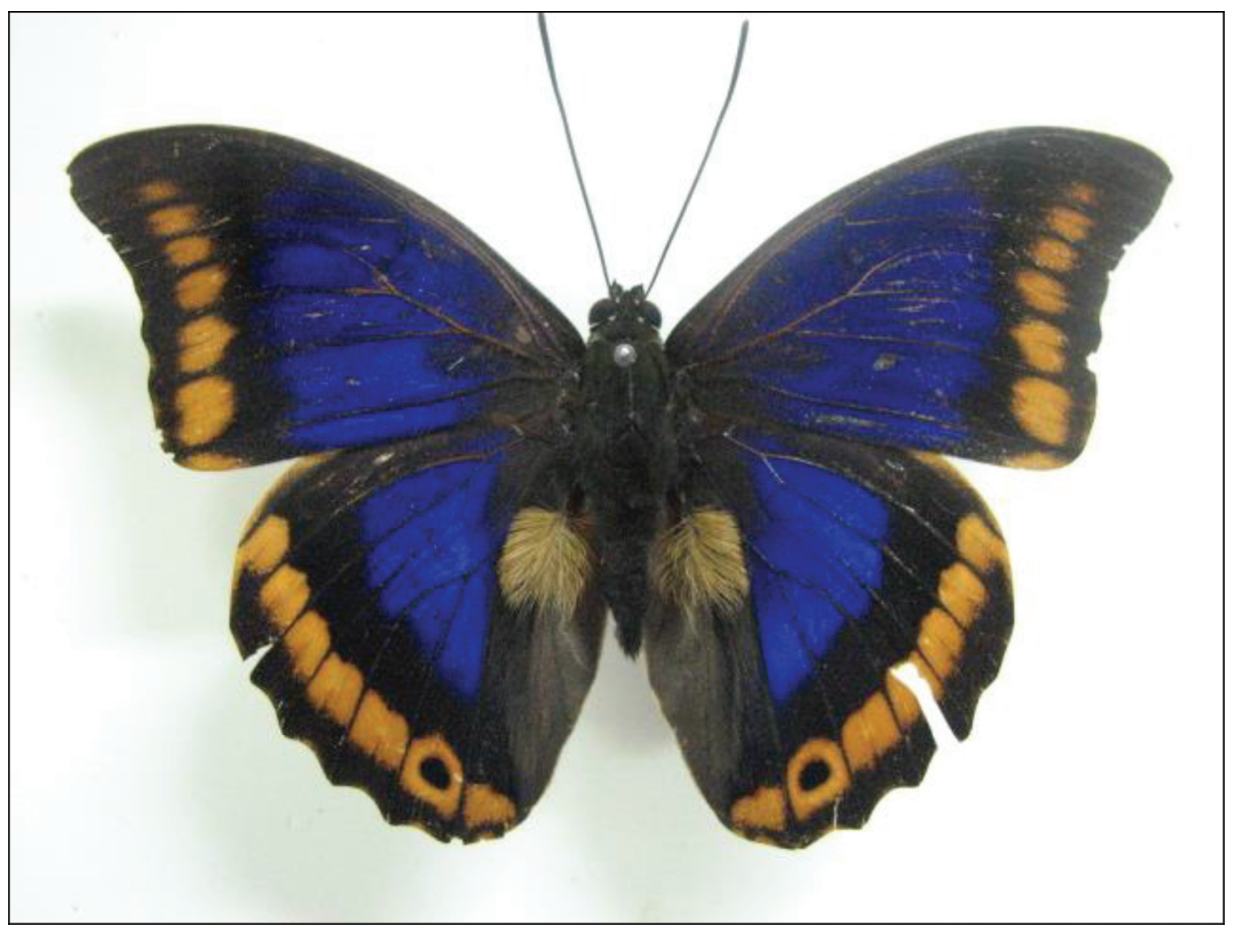

Figure 2. Male Prepona deiphile deiphile. Species classified as vulnerable on the list of threatened Fauna of Minas Gerais (2006) and on the national list of threatened species.

riparian forest, Cerrado and transition area (Pinheiro \& Ortiz 1992); and in riparian and Cerrado areas of Campus Darcy Ribeiro in Brasília, there were thirty-one species (Pinheiro et al. 2008). The number of species found in the APE Mutuca was similar only to the Parque Nacional da Serra do Canastra (MG), where sixteen fragments of riparian vegetation were sampled, and sixty-seven species were registered (Marini-Filho \& Martins 2010).

Regarding the region of Belo Horizonte, Brown \& Mielke (1968) registered forty nine species of fruit-feeding butterflies (eight exclusive records this location) and estimated 107 species for the city. Silva et al. (2007) studied an urban area of Belo Horizonte, finding seventeen species of fruit-feeding butterflies, four of which had not been found by Brown \& Mielke (1968) and one was not recorded in this study; Nica flavilla. Silva et al. (2012) studied an area in Belo Horizonte (APE Cercadinho), registering forty-five species, two exclusive ones. Soares et al. (2012) studied other urban area, in the centre of Belo Horizonte, finding fifteen species, with one exclusive to this area (Eteona tisiphone, Satyrinae).

Five of the seven surveys conducted in the region of Belo Horizonte had fourteen species in common: Biblis hyperia

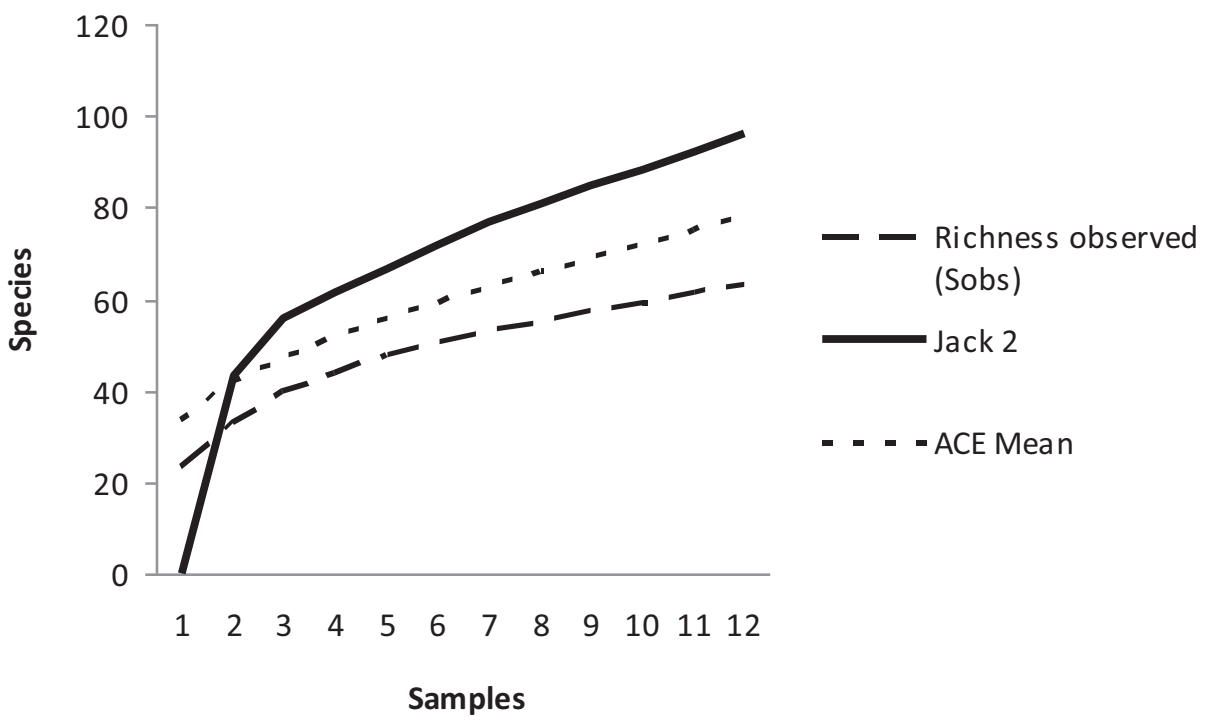

Figure 3. Species accumulation curve of butterflies recorded at the Área de Proteção Especial Manancial Mutuca, Nova Lima, MG, Brazil, between October 2008 and September 2009. 
Silva, A.R.M. et al.

Table 2. Estimators of species richness and proportion of the number of species observed in APE Mutuca and of the compiled species in the region of Belo Horizonte.

\begin{tabular}{lccc}
\hline $\begin{array}{l}\text { Estimators of species } \\
\text { richness }\end{array}$ & $\begin{array}{c}\text { Estimated number of } \\
\text { species }\end{array}$ & $\begin{array}{c}\text { Proportion of observed } \\
\text { species (63) }\end{array}$ & $\begin{array}{c}\text { Proportion of species compiled list for Belo } \\
\text { Horizonte (104) }\end{array}$ \\
\hline Chao 2 & 107 & $59 \%$ & $97 \%$ \\
Jackknife & 95 & $66 \%$ & $109 \%$ \\
ACE & 79 & $80 \%$ & $131 \%$ \\
\hline
\end{tabular}

nectanabis, Callicore sorana sorana, Hamadryas amphinome amphinome, Hamadryas epinome, Hamadryas februa februa, Hamadryas feronia feronia (Biblidinae), Colobura dirce (Nymphalinae), Brassolis sophorae laurentii, Blepolenis batea batea, Opsiphanes invirae, Morpho helenor mielkei, Paryphthimoides phronius, Paryphthimoides poltys and Taygetis laches (Satyrinae). These species could be the focus of population studies at the regional scale (eg: long-term monitoring), since most of them are easily identified and occur with high abundance in the samples.

From the fruit-feeding butterflies species found in collections, seventy-one were identified in the collection of $\mathrm{MCN}$ PUC-MG, including twelve exclusive species this collection. In the Coleção Entomológica da UFMG sixty species were identified, with three exclusive ones, while in the collection of MHNJB-UFMG fourteen species of fruit-feeding butterflies were recorded, neither exclusive specie.

In APE Mutuca, six species, which were not recorded in any of the studies or collections mentioned above, were sampled, and are new records for the region of Belo Horizonte: Myscelia orsis, Prepona deiphile deiphile, Prepona laertes, Catoblepia amphirhoe, Narope cyllastros and Pareuptychia ocirrhoe interjecta. Adding the records of the four papers (Brown \& Mielke 1968, Silva et al. 2007, Silva et al. 2012, Soares et al. 2012), the three collections and the present study, the total number of fruit-feeding butterflies in the region of Belo Horizonte is of 104 species. Brown \& Freitas (2000), referring to articles, collections, an personal communication, recorded eighty species of fruit-feeding butterflies in Belo Horizonte.

The species accumulation curve of APE Mutuca showed no clear stabilization trend (Figura 3), indicating that other species could be recorded with increasing sampling effort, a result corroborated by the richness estimators. The estimated species richness reached 107 species by the Chao 2 estimator, ninetyfive species by the Jackknife 2 estimator, and seventy-nine species by ACE estimator (Table 2). Therefore, the complied list in this study, with 104 species in the region of Belo Horizonte, approaches the richness achieved by estimators Chao 2 and Jackknife 2 for SPA Mutuca (Table 2). The Chao 2 estimator was closer to the list of Belo Horizonte (104 species), with an estimate of 107 species, indicating a congruence between the locally estimated and regionally observed values for fruit-feeding butterflies.

The number of fruit-feeding butterflies species recorded in this study (sixty-three) may be considered high, especially if it is taken into account that the APE Mutuca is a relatively small vegetation sample (1250 ha). The present study demonstrates that the APE Mutuca is essential for the maintenance of local diversity of butterflies because, even though the area is subjected to anthropogenic impact, it harbors an important portion of the fruit-feeding butterfly fauna in the region including thirty-five rare and one endangered species. This study also reinforces the importance of the creation and preservation of protected areas, even near large cities, for the maintenance of biodiversity at the regional scale.

\section{Acknowledgements}

To Centro Universitário UNA, to the biologist Maria Aparecida Souza (COPASA - MG), to Eduardo Carneiro (UFPR) for the critical reading, to professor Dr. André Victor Lucci Freitas (Universidade Estadual de Campinas, UNICAMP) for the identification of the species, and to all that helped in the samplings.

\section{References}

BAZ, A. \& BOYERO, A.G. 1995. The effects of forest fragmentation on butterfly communities in central Spain. J. Biogeogr. 22:129-140, http://dx.doi.org/10.2307/2846077

BIODIVERSITAS. 2006. Lista da Fauna Ameaçada de Extinção de Minas Gerais. http://www.biodiversitas.org.br/listas-mg/MG-especies-Fauna-ameacadas.pdf. (último acesso em 30/05/2011).

BRANDÃO, M., FERREIRA, P.B.D. \& ARAUJO, M. G. 1997. Mais uma contribuição para o conhecimento da Cadeia do Espinhaço em Minas Gerais - VI: Serra do Rola Moça. Daphne 7(4):50-64.

BROWN, J. \& LOMOLINO, M. 2006. Biogeografia. 2 ed. FUNPEC Editora, Ribeirão Preto.

BROWN JR., K.S. 1996. Diversity of Brazilian Lepidoptera: history of study, methods for measurements, and use as indicator for genetic, specific and system richness. In Biodiversity in Brazil: a first approach (C.E.M. Bicudo \& N.A. Menezes, eds). Instituto de Botânica, São Paulo, p.121-153.

BROWN JR., K.S \& FREITAS, A.V.L. 2000. Atlantic Forest butterflies: indicators for landscape conservation. Biotropica 32(4): 934-956, http://dx.doi.org/10.1111/btp.2000.32.issue-4b

BROWN JR., K.S \& MIELKE, O.H.H. 1968. Lepidoptera of the Central Brazil Plateau. III. Partial list for the Belo Horizonte area, showing the character of the southeastern "Blend Zone". J. Lepid. Soc. 22(3):147-157.

CAMARGO, A.J.A., 2001. Importância das Matas de Galeria para a conservação de lepidópteros do Cerrado. In Cerrado: caracterização e recuperação de Matas de Galeria. (J.F. Ribeiro, C.E.L. Fonseca \& J.C. Sousa-Silva, eds.) Embrapa, Planaltina, p.607-634.

CETEC. Fundação Centro Tecnológico de Minas Gerais. 1993. Desenvolvimento de metodologia (técnicas) para recuperação do revestimento florístico natural em áreas de proteção das captações de água da COPASA na região da grande Belo Horizonte. Relatório Técnico. CETEC, Belo Horizonte.

COPASA. 2013. Reservas Ambientais. http://www.copasa.com.br/cgi/ cgilua.exe/sys/start.htm?sid $=157 \&$ infoid $=104 \&$ tpl $=$ section.$h t m$ (último acesso em 10/06/2013).

COLWELL, R.K. 2009. Estimates Version 8.2: statistical estimation of species richness and shared species from samples. University of Connecticut, Connecticut. http://viceroy.eeb.ucon.edu/estimates. 
DAJOZ, R. 1983. Ecologia Geral. 4 ed. Editora Vozes, Petrópolis.

DE VRIES, P. 1987. The butterflies of Costa Rica and their natural history. Papilionidae, Pieridae, Nymphalidae. Princeton University Press, Princeton.

DE VRIES, P.J, MURRAY, D. \& LANDE, R. 1997. Species diversity in vertical, horizontal, and temporal dimensions of a fruit-feeding butterfly community in an Ecuadorian rainforest. Biol. J. Linn. Soc. 62:343-364, http://dx.doi.org/10.1111/bij.1997. 62.issue-3

DE VRIES, P.J, WALLA, T.R \& GREENEY, H.F. 1999. Species diversity in spatial and temporal dimensions of a fruit-feeding butterfly community from two Ecuadorian rainforest. Biol. J. Linn. Soc. 68:333-353, http://dx.doi.org/10.1111/bij.1999.68.issue-3

DE VRIES, P.J, PENS, C.M \& HILL, R.I. 2010. Vertical distribution, flight behavior and evolution of wing morphology in Morpho butterflies. J. Anim. Ecol. 79:1077-1085, http://dx.doi.org/10.1111/ j.1365-2656.2010.01710.x

DE VRIES, P.J, ALEXANDER, L.G, CHACON, I.A \& FORDYCE, J. A. 2011. Similarity and difference among rainforest fruit-feeding butterfly communities in Central and South America. J. Anim. Ecol. 81:472-482, http://dx.doi.org/10.1111/j.1365-2656.2011.01922.x

FORTUNATO, L. \& RUSZCZYK, A. 1997. Comunidades de Lepidópteros frugívoros em áreas verdes urbanas e extra-urbanas de Uberlândia, MG. Rev. Brasil. Biol. 57(1):79-87.

FREITAS, A.V.L \& ALMEIDA, A.C. 2012. Lepidoptera: borboletas e mariposas do Brasil. 1 ed. Exclusiva Publicações, São Paulo.

FREITAS, A.V.L., FRANCINI, R.B. \& BROWN JR., K.S. 2003. Insetos como indicadores ambientais. In Métodos de estudos em biologia e manejo da vida silvestre. (L. Cullen Jr, R. Rudran \& C. Valladares-Padua, eds). Curitiba, Editora da UFPR, p.125-151.

FREITAS, A.V.L. 2010. Impactos potenciais das mudanças propostas no Código Florestal Brasileiro sobre as borboletas. Biota Neotrop. 10(4):1-5. http://www.biotaneotropica.org.br/v10n4/pt/fullpaper? bn00810042010 + pt (último acesso em 20/03/2014).

KLINK, C.A. \& MACHADO, R.B. 2005. A conservação do cerrado brasileiro. Megadiversidade 1(1):147-155.

LAMAS, G. 2004. Atlas of Neotropical Lepidóptera: Checklist. Part 4A Hesperioidea e Papilionoidea. Scientific Publishers, Gainesville.

LEWINSOHN, T.M., FREITAS, A.V.L. \& PRADO, P.I. 2005. Conservação de Invertebrados terrestres e seus hábitats no Brasil. Megadiversidade 1(1):62-69.

MACHADO, A.B.M., MARTINS, C.S. \& DRUMMOND, G.M. 2005. Lista da Fauna Brasileira Ameaçada de Extinção. Fundação Biodiversitas, Belo Horizonte.

MAGURRAN, A.E. \& VIANNA, D.M. (Trad.) 2011. Medindo a diversidade biológica. Editora da UFPR, Curitiba.

MARÍN, M.A., PEÑA, C., FREITAS, A.V.L., WAHLBERG, N. \& URIBE, S I. 2011. From the Phylogeny of the Satyrinae Butterflies to the Systematics of Euptychiina (Lepidoptera: Nymphalidae): History, Progress and Prospects. Neotrop. Entomol. 40(1):1-13.

MARINI-FILHO, O.J. 2012. Comunicação pessoal.

MARINI-FILHO, O.J. \& MARTINS, R.P. 2010. Nymphalid butterfly dispersal among forest fragments at Serra da Canastra National Park, Brazil. J. Insect Conserv. 14:401-411, http://dx.doi.org/10.1007/s10841010-9271-9
MENDONÇA, M.P. \& LINS, L.V. 2000. Lista vermelha das espécies ameaçadas de extinção da flora de Minas Gerais. Belo Horizonte. Fundação Biodiversitas, Fundação Zôo-Botância de Belo Horizonte, Belo Horizonte.

MIELKE, O.H.H., CARNEIRO, E. \& CASAGRANDE, M.M. 2010. Lepidopterofauna (Papilionoidea e Hesperioidea) do Parque Estadual do Chandless e arredores, Acre, Brasil. Biota Neotrop. 10(4):285-300. http://www.biotaneotropica.org.br/v10n4/pt/fullpaper?bn03210042010 + pt (último acesso em 16/02/2014).

MYERS, N., MITTERMEIER, R.A., MITTERMEIER, C.G., FONSECA, G.A.B. \& KENT, J. 2000. Biodiversity hotspots for conservation priorities. Nature 3:853-858.

PINHEIRO, C.E.G. \& ORTIZ, J.V.C. 1992. Communities of FruitFeeding Butterflies along a vegetation gradiente in Central Brazil. J. Biogeog. 19:505-511, http://dx.doi.org/10.2307/2845769

PINHEIRO, C.E.G., MALINOV, I.C., ANDRADE, T.O., MARAVALHAS, J.B., ANDRADE, M.B.M., DEUS, L.P.A., PEDROSA, L.G.P. \& ZANATTA, G.V. 2008. As borboletas (Lepidoptera: Papilionoidea) do Campus Universitário Darcy Ribeiro (Distrito Federal, Brasil). Biota Neotrop. 8(4):138-144. http://www.biotaneotropica.org.br/v8n4/pt/ fullpaper?bn00608042008 + pt (último acesso em 20/02/2013).

RITTER, C.D., LEMES, R., MORAIS, A.B.B. \& DAMBROS, C.S. 2011. Borboletas (Lepidoptera: Hesperioidea e Papilionoidea) de fragmentos de Floresta Ombrófila Mista, Rio Grande do Sul, Brasil. Biota Neotrop. 11(1):1-8. http://www.biotaneotropica.org.br/v11n1/pt/fullpaper?bn00511012011 + pt (último acesso em 27/04/2013).

SHAHABUDDIN, G. \& PONTE, C.A. 2005. Frugivorous butterfly species in tropical forest fragments: correlates of vulnerability to extinction. Biodiv. Conserv. 14:1137-1152, http://dx.doi.org/10.1007/ s10531-004-7842-3

SILVA, A.R.M., LANDA, G.G. \& VITALINO, R.F. 2007. Borboletas (Lepidoptera) de um fragmento de mata urbano em Minas Gerais, Brasil. Lundiana 8(2):137-142.

SILVA, A. R. M., CASTRO, C. O., MAFIA, P. O., MENDONÇA, M. O. C., ALVES, T. C. C. \& BEIRÃO, M. V. 2012. Borboletas frugívoras (Lepidoptera: Nymphalidae) de uma área urbana (Área de Proteção Especial Manacial Cercadinho) em Belo Horizonte, Minas Gerais, Brasil. Biota Neotrop. 12(3):292-297. http://www.biotaneotropica.org. br/v12n3/pt/abstract?inventory + bn03112032012 (último acesso em 17/ 09/2013), http://dx.doi.org/10.1590/S1676-06032012000300028

SOARES, G. R., OLIVEIRA, A. A. P. \& SILVA, A. R. M. 2012. Borboletas (Lepidoptera: Papilionoidea and Hesperioidea) de um parque urbano em Belo Horizonte, Minas Gerais. Biota Neotrop. 12(4):209-217. http://www.biotaneotropica.org.br/v12n4/pt/fullpaper?bn02612042012 + pt (último acesso em 11/04/2013), http:// dx.doi.org/10.1590/S1676-06032012000400022

UEHARA-PRADO, M., FREITAS, A.V.L.; FRANCINI, R.B. \& BROWN JR., K.S. 2004. Guia das borboletas frugívoras da Reserva Estadual do Morro Grande e região de Caucaia do Alto, Cotia (São Paulo). Biota Neotrop. 4(1):1-25. http://www.biotaneotropica.org.br/ v4n1/pt/download?article + BN00504012004 + abstract (último acesso em 12/10/2012).

WILSON, E.O. 1997. A situação atual da diversidade biológica. In Biodiversidade. (E.O. Wilson \& F.M. Peter, eds). Editora Nova Fronteira, Rio de Janeiro, p.3- 